\title{
EXPLORAÇÃO AURÍFERA ARTESANAL E A MIGRAÇÃO DE GARIMPEIROS PARA O TERRITÓRIO RONDONIENSE
}

\author{
ARTISANAL GOLD MINING EXPLORATION AND THE MINERS OF \\ MIGRATION TO THE RONDÔNIA'S TERRITORY \\ EXPLOTACIÓN AURÍFERA ARTESANAL Y LA MIGRACIÓN DE MINEROS \\ PARA EL TERRITORIO RONDONIENSE
}

\author{
Joiada Moreira da Silva Linhares ${ }^{1}$ \\ Wanderley Bastos Rodrigues ${ }^{2}$ \\ José Manoel Carvalho Marta ${ }^{3}$
}

\begin{abstract}
Resumo: A procura por ouro e pedras preciosas, a século impulsionam a migração de garimpeiros para a Amazônia. No sul da Amazônia as migrações de faiscadores ou garimpeiros iniciaram com a descoberta das minas auríferas cuiabanas e guaporeanas, ainda no período colonial. Estas motivaram a migração e o povoamento do vale do Rio Guaporé em especial no território rondoniense. Neste espaço, durante o século XX, houve a descoberta de novas jazidas de ouro, cassiterita e diamante; cujas auríferas têm maior importância nos estudos demográficos e econômicos regionais. Neste contexto, o objetivo do presente estudo foi analisar o ciclo de exploração aurífera artesanal e a migração de garimpeiros de 1978 a 1995 para o território rondoniense. A partir da teoria de ciclo econômico schumpeteriana foi possível reconhecer cinco ciclos de exploração aurífera em Rondônia sendo, dois relacionados à descoberta de novas fontes de matéria prima mineral (ciclo do ouro de 1721 a 1765 e, da cassiterita entre 1952 e 1970), e três pertinentes a introdução de novos métodos de produção mineral, até então não experimentados na antiga reserva garimpeira do rio Madeira, tais como: lavra manual (1978 a 1981), extração por meio de balsas (1981 a 1985) e dragas garimpeiras (1986-1992). Até hoje, não se sabe o volume exato de ouro extraído bem como, quantos garimpeiros com ou sem experiência de prospecção mineral, migraram para o território rondoniense. Apesar disso, os garimpeiros além de contribuírem no povoamento da Amazônia, também ajudaram a saldar uma parte da dívida externa do país junto aos bancos internacionais.
\end{abstract}

Palavras chave: garimpeiros, migração, mineração, ciclo aurífero.

\footnotetext{
${ }^{1}$ Mestre em Desenvolvimento Regional e Meio Ambiente. Pesquisador de apoio técnico no Laboratório de Biogeoquímica Ambiental Wolfang C. Pfeiffer, Universidade Federal de Rondônia. Professor do Ensino Básico, Técnico e Tecnológico do Instituto Federal de Educação, Ciência e Tecnologia do Amazonas, Campus Lábrea. Doutorando no Programa de Pós-graduação em Desenvolvimento Regional e Meio Ambiente da Fundação Universidade Federal de Rondônia. Bolsista da Fundação de Amparo à Pesquisa do Amazonas - FAPEAM. Email: joiada.linhares@gmail.com.

${ }^{2}$ Doutorado (2004) em Ciências Biológicas (Biofísica Ambiental) no Instituto de Biofísica Carlos Filho da Universidade Federal do Rio de Janeiro. Atualmente é Professor Associado II pelo Departamento de Biologia.

${ }^{3}$ Doutor em Planejamento de Sistemas Energéticos pela Universidade Estadual de Campinas (2002). Professor aposentado Associado II da Faculdade de Economia da Universidade Federal de Mato Grosso da disciplina Desenvolvimento Econômico e Social na Graduação e Desenvolvimento no Mestrado em Agronegócios e Desenvolvimento Regional.
} 


\begin{abstract}
The search for gold and precious stones, the century drives the migration of miners to the Amazon. In the south of the Amazon, the migrations of miners started with the discovery of the cuiabanas and guaporeanas gold mines, still in the colonial period. These motivated the migration and the settlement of the valley of the Guaporé river especially in the rondônia's territory. In this space, during the $20^{\text {th }}$ century, there was the discovery of new gold deposits, cassiterite and diamond. Among these, the golds have more importance in regional demographic and economic studies. In this context, the objective of the present study was to analyze the cycle of artisanal gold exploration and the migration of miners from 1978 to 1995 . From the theory of economic cycle schumpeteriana it was possible to recognize five cycles of gold exploration in Rondônia being, two related to the discovery of new sources of mineral raw material (gold cycle between 1721 to 1765 and, of cassiterite between 1952 and 1970 in the rondônia's territory), and three relevant the introduction of new methods of mineral production, until then untried in the former Madeira river mining reserve, such as: extraction tilling (1978 to 1981), extraction through of ferries (1981 to 1985) and dredgers mining (1986-1992). Until today, no one knows the exact volume of gold extracted as well as, how many miners with or without experience mineral prospecting, migrated to the rondônia's territory. Despite this, the miners, besides contributing in the settlement of the Amazon, also helped to pay off part of the external debt of the country with the international banks.
\end{abstract}

Keywords: miners, migration, mining, cycle gold.

Resumen: La búsqueda de oro y piedras preciosas desde siglos impulsan la migración de mineros hacia la Amazonia. En el sur de la Amazonia las migraciones de faisadores o mineros comenzaron con el descubrimiento de las minas auríferas cuiabanas y guaporeanas, aún en el período colonial. Estas motivaron la migración y el poblamiento del valle del Río Guaporé en especial en el territorio rondoniense. En este espacio, durante el siglo XX, hubo el descubrimiento de nuevos yacimientos de oro, casiterita y diamante; cuyas auríferas tienen mayor importancia en los estudios demográficos y económicos regionales. En este contexto, el objetivo del presente estudio fue analizar el ciclo de explotación aurífera artesanal y la migración de mineros de 1978 a 1995 hacia el territorio rondoniense. A partir de la teoría de ciclo económico schumpeteriana fue posible reconocer cinco ciclos de explotación aurífera en Rondônia siendo, dos relacionados al descubrimiento de nuevas fuentes de materia prima mineral (ciclo del oro de 1721 a 1765 y de la casiterita entre 1952 y 1970), y en el caso de las aguas residuales, en el caso de las aguas residuales, se observó un aumento en la producción de agua potable, 1992). Hasta hoy, no se sabe el volumen exacto de oro extraído así como, cuántos mineros con o sin experiencia de prospección mineral, emigraron al territorio rondoniense. A pesar de ello, los mineros además de contribuir al poblamiento de la Amazonia, también ayudaron a saldar una parte de la deuda externa del país junto a los bancos internacionales.

Palabras clave: mineros, migración, minería, ciclo aurífero. 


\section{Início da exploração mineral e do povoamento na Bacia do Rio Madeira}

O mito da abundância inexaurível de riquezas minerais tem atraído para a Amazônia, em especial para o território rondoniense, centenas de exploradores e aventureiros que têm esperança de a qualquer tempo deparar-se com um "pote de ouro" encravado em ambiente geológico primário ou secundário. Foi este espírito que motivou, dentre outros fatores, vários exploradores a desagarrarem-se do litoral e a embrenharem-se na floresta amazônico em busca de metais preciosos e outras especiarias tropicais.

Os pioneiros dessa aventura foram os espanhóis e os portugueses, que descobriram ricos depósitos mineralizados de prata e ouro em suas colônias latino-americana. A união geopolítica das monarquias da península Ibérica propiciou a redução ${ }^{4}$ das excursões geológicas lusitanas na Amazônia, pois o volume de prata extraído das minas de Cerro Potosí, província mineradora situada na região Andina próxima a seção da nascente do Rio Grande (atual território boliviano), supria a demanda econômica de prata e ouro da coroa espanhola e portuguesa. Fato que adiou por alguns anos a ocupação definitiva do vale do Guaporé pelos portugueses.

Em meados do século XVII, com a dissolução da união Ibérica, Portugal retomou as prospecções minerais na Amazônia. Para tanto, passou a oferecer incentivos aos mineiros que encontrassem ouro no território espanhol de Nueva Andalucia. A partilha do ouro descoberto e extraído e os títulos de nobre e de oficial militar da Coroa portuguesa marcaram a retomada das expedições geológicas além dos limites do meridiano de Tordesilhas. Entretanto, somente no início do século XVIII, precisamente, em 1716, foram descobertas as minas mais expressivas de ouro no extremo meridional da Amazônia, quando as excursões bandeirantes a serviço da Coroa portuguesa descobriram as minas auríferas do Rio Caxipo-Mirim (afluente do rio Cuiabá). Novos achados auríferos ocorreram quinze anos mais tarde, na porção sul da capitania mato-grossense, às margens dos rios Sararé, Galera e Corumbiara (território rondoniense), todos afluentes do Rio Guaporé e pertencentes a bacia do Rio Madeira (QUEIROZ, 2009).

\footnotetext{
${ }^{4}$ Por volta de 1678 religiosos da Companhia de Jesus na condição de garimpeiros já extraiam ouro às margens dos rios Gurupi e Piriá (Amazônia Oriental) com auxílio de escravos. Mais informação sobre o tema. CPRM Companhia de Pesquisa e Recursos Minerais do Brasil. Disponível em: <http://www.cprm.gov.br/publique/Geologia/Geologia-Basica/Projeto-Turiacu-\% 7C-Pinheiro-435.html.
} 
Atraídos pelos veios auríferos, uma numerosa força de trabalho deslocou-se rumo à região da nascente e médio curso do Rio Guaporé. Este fluxo populacional possibilitou a formação de uma sociedade heterogênea, composta por vassalos da coroa portuguesa, castelhanos, africanos (escravos fugitivos e libertos) e nativos, cujas peculiaridades étnicas foram responsáveis pela existência de tensões e constantes conflitos no interior da emergente sociedade colonial na fronteira do Guaporé (FARIAS JUNIOR, 2011).

A estratégia de ocupação através da exploração mineral, incentivada pela Coroa portuguesa no vale do Rio Guaporé, resultou na formação de vários povoados, geopolítica que vai ser consolidada com a criação da capitania do Mato Grosso em 1748 e de Vila Bela da Santíssima Trindade, fundada em 1752 (CAVOVA, 2011). O limite territorial da nova capitania era superior a 500 léguas $(\approx 2.414 \mathrm{~km})$, e estendiam-se até a comunidade da cachoeira Santo Antônio do Rio Madeira, fundada pelo padre jesuíta João Sampaio (TEIXEIRA, 1998). Curiosamente, o mesmo limite territorial do extremo norte da reserva garimpeira do Rio Madeira, criada no final dos anos de 1970, do século XX. Coincidência geográfica ou os portugueses tinham conhecimento da existência de ouro no trecho encachoeirado do rio Madeira?

Entre 1721 e 1765 a mineração artesanal intensificou-se no vale do Rio Guaporé e propiciou a primeira grande migração garimpeira rumo ao território guaporeano. No auge deste período, estima-se que em média eram extraídos $1.150 \mathrm{Kg}$ ouro por ano das minas cuiabanas e guaporeanas. A partir de 1799, houve um acentuado declínio na atividade de mineração e na produtividade das minas auríferas sul mato-grossenses. Entretanto, há relatos históricos que confirmam a manutenção da lavra faisqueira, praticada de forma artesanal (garimpagem manual) pelos habitantes da região guaporeana que perdurou durante todo o século XIX (RUSSELL-WOOD, 1999; FARIAS JUNIOR, 2011).

Em 1826, Luís d'Alincourt, após transpor quinze das dezenove cachoeiras, em sua viagem do Porto de Santos à cidade de Cuiabá, de passagem pela Amazônia, nos rochedos da margem direita da cachoeira do Rio Ribeirão, registrou em seu diário de viagem pela primeira vez a existência de fagulhas de ouro no grande Rio Madeira. Informação que mais tarde propiciaria a (re)configuração da paisagem natural da bacia do Rio Madeira (ALINCOURT, 2014).

No princípio da década de 1950, garimpeiros explorando as terras do seringal do Sr. Joaquim Pereira Rocha, localizado no vale do Rio Machadinho (afluente do Rio Jamari que 
por sua vez é afluente do Rio Madeira) descobrem as primeiras jazidas de cassiterita no então Território Federal do Guaporé, recém-criado pelo presidente Getúlio Vargas. Ao saber da notícia o governo Federal enviou em 1952 o engenheiro Frederico Hoespken, que constatou a presença do minério na localidade (FERREIRA, 1996). Na ocasião a cassiterita apresentava alto preço no mercado internacional. Essas notícias espalharam-se por toda a região, estimulando outros seringueiros a realizarem pesquisas em suas terras em busca de cassiterita (FERREIRA, 1961).

A esse respeito, diz a história que a descoberta das minas estaníferas pôs fim ao longo período de estagnação econômica da atividade extrativista mineral que encontrava-se o território do Guaporé. Este é fato real, uma vez que a extração desse minério originou novamente uma expressiva "corrida garimpeira" (migração interna inter-regional) para sudoeste Amazônico, atraindo cerca de 10 mil mineradores de várias regiões do país para as minas de cassiterita rondoniense. No início dos anos de 1970, a mineração estanífera artesanal foi proibida em toda a província estanífera de Rondônia pelo Ministério de Minas e Energia (MME), que passou a concessão de exploração para a mineração industrial. Decisão que até hoje é motivo de conflitos entre garimpeiros autônomos e empresários do setor de mineração no garimpo de Bom Futuro, localizado do município de Ariquemes/RO (RAMOS, 2003).

No decorrer da década de 1970, diversas minas de cassiterita foram fechadas por causa da crise mundial do petróleo e queda acentuada no preço do estanho na bolsa de Metais de Londres e Mercantil de Futuro Brasileira. A produção de cassiterita em Rondônia decresceu rapidamente, fato que levou milhares de mineiros a migrarem (migração interna intra e interregional) para outras áreas de exploração mineral existentes no território rondoniense, matogrossense e amazonense, a exemplo das jazidas auríferas do Alto Rio Madeira, Serra Pelada, Peixoto de Azevedo entre outras (RAMOS, 2003).

Ao contrário do estanho, no final dos anos de 1970, o ouro subiu de preço no mercado internacional, viabilizando economicamente a extração mineral nas "barrancas" e, posteriormente no leito do Rio Madeira. A partir dos anos de 1980, a mineração aurífera no vale do Rio Madeira intensificou-se, atraindo para o noroeste rondoniense centenas de garimpeiros, notadamente do Maranhão, Ceará e Pará, e procedentes geralmente de outras áreas de mineração como Santa Rosa de Roraima, Serra Pelada, Tapajós (PA), Maués e Parauari (AM), Alto Aripuanã e Alta Floresta (MT) (ADAMY, 1991). Atividade que gradativamente proporcionou uma transformação socioeconômica e ambiental na área dos 
vilarejos situados ao longo das vias de circulação interestadual rondoniense entre Porto Velho e Guajará Mirim.

A combinação de vários fatores econômicos e políticos contribuiu para que ocorresse no final da década de 1980 a intensificação da atividade de mineração aurífera no território rondoniense, com destaque para: o aumento significativo do preço de ouro no mercado internacional, no qual o valor da onça troy, que era comercializada a US\$ 31 em 1973, teve uma súbita alta nunca antes vista, atingindo valores máximos de US\$ 850 em 1981; recuperação e pavimentação das rodoviárias BR-364 que interliga Rio Branco (Acre) ao Distrito Federal e a BR-425 que interliga a Vila de Abunã (RO) à cidade de Guajará-Mirim (RO). Estes eixos rodoviários facilitaram o fluxo de mercadorias e trabalhadores do Centrosul e Nordeste do país para as cidades de Porto-Velho e Guajará-Mirim, que assumiram o papel de centros comerciais de apoio logístico da província aurífera do Rio Madeira, instalada no final dos anos setenta pelo Ministério de Minas e Energia (MME) (SANTOS, 2002).

A delimitação da província garimpeira rondoniense significou, no governo militar do General João Batista de Oliveira Figueiredo, o domínio geopolítico das jazidas auríferas existentes no Alto Rio Madeira. Estratégia que propiciou uma nova (re)configuração territorial do trecho encachoeirado do rio Madeira. Esta difere daquela ocorrida entre 1907 e 1912, quando Percival Farquhar (industrial norte-americano) fundou a empresa ferroviária Madeira-Mamoré Railway Co., que contratou a empreiteira May Jekyll \& Randolph Co, Ltda., para construir a Estrada de Ferro Madeira Mamoré (EFMM) ${ }^{5}$, inaugurada em 1912 (TEIXEIRA, 2014).

Para entender a história por detrás da criação da reserva garimpeira do Rio Madeira, fomos buscar em, Schumpeter (1997), Perdigão e Bassegio (1992), Becker (1991), Martins e Vanalli (1997), Ramos (2003), Bastos e Lacerda (2004), Veigas e Hinton (2002), a compreensão teórica sobre a exploração de minério artesanal e as razões que motivaram centenas de garimpeiros a migrarem para o território rondoniense. Esses últimos autores, aprofundam-se nas questões que pairam sobre a exploração aurífera artesanal e as causas que tornaram as reservas garimpeiras da Amazônia, em especial do Alto Rio Madeira (Rondônia), uma área "ecúmina", ou seja, favorável à atração humana.

\footnotetext{
${ }^{5}$ Estima-se que entre 1907 e 1912 a construtora Jekyll \& Randolph Co. contratou mais de 21.783 trabalhadores (imigrantes) de diversas nacionalidades, tais como: italianos, norte-americanos, ingleses, gregos, hindus, espanhóis, portugueses e principalmente barbadianos.
} 
Inúmeros são os motivos que impulsionam (catástrofes, perseguições políticas e religiosas, repressão, rivalidade étnica, revolução armada e sobrevivência) as pessoas a deixarem seus lugares de origem e migrarem para outras localidades. Entretanto, as razões de ordem econômica são, sem dúvida alguma, a principal motivação das migrações em escala local, região e global (DAMIANI, 2009).

A procura de sustento e melhores condições de vida levou milhares de famílias a migrarem para a Amazônia, estimulados pela oferta de terra. Mas nem todos os homens (chefes de família) vieram para o norte em busca de terra, um contingente considerável migrou, especialmente, para o território rondoniense atraídos pelo sonho de enriquecer, logo ao saber da existência de jazidas estaníferas e auríferas, nesta parte da Amazônia (MARTINS; SÔNIA, 1997). A esse respeito, Becker (1991) argumenta que dois fatores explicam a corrida garimpeira e a migração de trabalhador para a Amazônia, durante e após a ditadura militar: o primeiro relaciona-se ao surgimento do garimpo, que tem início como uma estratégia de sobrevivência para uma parcela considerável da população economicamente ativa, formada por trabalhadores sem terra e sem emprego estável. O segundo fator refere-se à possibilidade de rápida capitalização do trabalhador (garimpeiro) na condição de solteiro ou chefe de família camponesa. Nesse contexto, o Estado ditatorial e os empresários do setor de mineração enxergavam o garimpeiro como um "habilidoso" caçador de riquezas minerais ou de minérios, mesmo sem nunca ter sentado um único dia, no banco escolar para aprender técnica de prospecção de mineiro. E o garimpo? Este era visto como "válvula reguladora" das tensões e conflitos sociais que ocorriam no espaço urbano e rural brasileiro, bem como espaço para obtenção de emprego alternativo para o exercício de reserva, ou seja, população economicamente ativa desempregada (SILVA, 2002).

Para Martins e Sônia (1997), o fluxo migratório rumo a Amazônia, nos anos de 1970, foi induzido pelo Estado, quando os governos militares instalaram na região diversos projetos, tais como: Plonamazônia - Programa de Pólos Agropecúarios e Agrominerais da Amazônia, PGC - Programa Grande Carajás, PNO - Política Nacional de Ouro e o PNAIO - Programa Nacional de Ação Integrada para o Ouro. Estes foram implementados em áreas específicas na Amazônia, visando a atender determinados grupos econômicos nacionais e internacionais que tinham interesses nos recursos minerais da região. Entretanto, os programas necessitavam de uma vultosa mão de obra, de preferência barata. É nesse momento que entra o Estado (governo dos militares), ao divulgar pelo País, (regiões Nordeste, Sul e Sudeste) que na 
Amazônia estava sobrando terra, minério e emprego; propaganda que estimulou a migração de trabalhador desempregado (pobre) do Centro-Sul, que ao tomar conhecimento da notícia não pensava duas vezes, deixava a terra natal e partia para a região amazônica na esperança de uma vida melhor.

Embora a ocupação humana do território rondoniense tenha se intensificado a partir de 1970, Perdigão e Bassegio, (1992) e Lisboa et al. (1995) afirmam que o processo de migração estimulado pelo Estado, não é recente e remonta ao século XVIII, mais precisamente 1776; quando para construir o Forte Príncipe da Beira na confluência do Rio Guaporé como Rio Boliviano San Miguel, a Corroa Portuguesa enviou dois engenheiros e duzentos trabalhadores para o vale do Guaporé. A partir dessa intervenção, o fluxo migratório para o território rondoniense foi marcado por sucessivos ciclos econômicos, tais como: primeiro ciclo da borracha de 1877 a 1912 (migração de nordestinos), segundo ciclo da borracha entre 1943 e 1945, ciclo da mineração estanífera artesanal e empresarial de 1950 a 1980 (migração de garimpeiros), ciclo da colonização dirigida de 1970 a 1980 e, concomitante a colonização o ciclo da mineração aurífera artesanal de 1978 a 1992. Dentre esses ciclos econômicos, poucos trabalhos têm sido realizados sobre a contribuição que o ciclo da mineração de ouro teve no povoamento do território rondoniense.

A discussão sobre a migração de garimpeiros para o então Território Federal de Rondônia teve um caráter estratégico no desenvolvimento econômico e no processo de acumulação de capital, esta vai muito além da concepção simplista colocada pelo estado ditatorial ao divulgava no espaço nacional, a necessidade de ocupar os espaços vazios do brasil setentrional e integrá-los a economia nacional. Nesse sentido, faz necessário compreender a teórica schumpeterina sobre ciclo econômico.

Segundo Schumpeter (1997), o que marca o início e o fim de um ciclo econômico no capitalismo é o aparecimento de inovações significativas que possibilitam o rompimento do "fluxo circular" ou estacionário de uma economia (nacional ou regional) no espaço e no tempo. Processo que dar-se-á mediante: i) a introdução de um novo produto no mercado consumidor; ii) introdução de um novo método de produção, ainda não experimentado pelo setor secundário; iii) abertura de um novo mercado, ainda não explorado pelo seguimento industrial; iv) reconfiguração de uma indústria qualquer, como a criação ou fragmentação de um monopólio; e, finalmente, v) a descoberta e/ou oferta de uma nova fonte, (economicamente viável) de matéria-prima ou de bens semimanufaturados. A este respeito, a 
descoberta de jazidas secundárias com alto teor de cassiterita e ouro entre outros fatores possibilitaram o ciclo da mineração no território rondoniense. Todavia, este fato levanta uma questão: quantos ciclos de mineração ocorreram no território rondoniense uma vez que as jazidas foram descobertas em período distintos?

Na teoria schumpeteriana, a periodicidade de um ciclo variará entre o momento que uma inovação começa a produzir e comercializar uma nova mercadoria e, a entrada de produtos similares, provenientes de inovações idênticas (imitações) ao mercado. A incerteza sobre o tempo exato do estabelecimento do período de prosperidade e depressão abre um precedente para a existência de ciclos econômicos com duração distintas, tais como: o ciclo e ondas longas de Kondratieff (duração média entre 54 a 60 anos), ciclo econômico de Juglar (duração média entre 9 e 10 anos) e o ciclo de Kitchin com duração de 2 a 3 anos ou 40 meses (SCHUMPETER, 1997). Partindo dessa premissa, é aceitável a possibilidade de ter ocorrido vários ciclos econômico de mineração artesanal no território rondoniense.

Esta contribuição, junto com as demais, mostra que a análise de ciclo econômico em qualquer tempo e espaço é complexo, isso demonstra que a confirmação cientifica do tempo efetivo de duração de um ciclo, não é uma tarefa trivial. Por isso, este estudo, não tem a pretensão de aprofundar, nesta ou naquela corrente teórica de ciclo econômico, e tão pouco enveredar pela quantificação de ciclos, na busca de estabelecer uma nova proposição teórica quanto a duração dos ciclos econômicos, mas valer-se da concepção cíclica apresentada na teoria schumpeteriana com a finalidade de estabelecer uma relação de causa e efeito quanto a exploração aurífera artesanal e migração de garimpeiros para o território rondoniense, em virtude da descoberta das jazidas auríferas do Alto Rio Madeira. Neste contexto, o objetivo do presente estudo é analisar o ciclo de exploração aurífera artesanal e a migração de garimpeiros entre 1978 e 1995 para o território rondoniense

\section{Metodologia}

O estudo foi desenvolvido por meio da consulta a diversos documentos nacionais e internacionais, disponibilizados na internet através de bancos de dados livres na web Science, SciElO, Periódicos Capes e no repositório de teses e dissertações no portal de domínio público do MEC. Além de acervos bibliográficos de instituições de ensino superior e de 
órgãos públicos envolvidos na prospecção de minérios, situados na cidade de Porto VelhoRO.

A seleção das informações na rede mundial de computadores foi realizada com a utilização de 15 palavras chave: garimpo, mineração, lavra, ouro, cassiterita, garimpeiro, migração, migrante, faiscador, jazida, aluvião, balsa, draga, técnica e tecnologia. Por meio destas, foram identificados mais de 4.800 documentos, entre livros e capítulos de livros digitais, teses, dissertações, relatórios técnicos, monografias artigos e resumos, etc. Critério semelhante foi adotado na coleta de informações (dados de produção de ouro e número de migrantes) nos acervos bibliográficos analógicos (ficha cadastral) em instituições públicas de Porto Velho-RO. Após triagem foram escolhidas 150 publicações consideradas relevantes para os objetivos da pesquisa. Essas, após análise de conteúdo e discurso (CARDOSO,1997) no tocante a atividade de mineração industrial, artesanal e, seus principais atores (garimpeiros, minérios, mineradores entre outros), foram organizadas de acordo com os temas abordados nesse Estudo.

\section{História etimológica do temo mineração e garimpagem}

É comum na sociedade rondoniense haver certa confusão quando se fala em técnica e tecnologia de mineração aurífera, pois há divergentes associações muitas vezes contraditórias a respeito do que é mineração e o que é garimpagem! Mineração é uma palavra que deriva do latim - mineralis -, que significa "minerais e / ou minas". É proveniente da ação de cavar minas que originou o verbo "minar"; no Século XVI e, em consequência da prática de se escavar fossos em torno das fortalezas, durante as guerras, com a finalidade de fazê-las ruir. Posteriormente adotou-se a palavra "mina" para designar explosivos militares. A associação das duas atividades deu origem ao termo mineração, visto que a escavação das minas se faz frequentemente com o auxílio de explosivos (AMARAL, 2016).

No sistema de classificação internacional estabelecido pela Organização das Nações Unidas (ONU), o termo mineração está relacionado à extração, elaboração e beneficiamento de minerais que se encontram em estado natural: sólido, como o ouro, cassiterita, diamante e outros; líquido, como o petróleo bruto; e gasoso, como o gás natural. Nessa concepção mais abrangente, inclui a exploração das minas subterrâneas e a céu aberto, incluindo-se aí todas as atividades complementares para preparar e beneficiar minérios, afim de torná-los 
comercializáveis, desde que não suceda alteração, em caráter irreversível, na sua condição geoquímica primária (AMARAL, 2016).

Nesse contexto, mineração artesanal caracteriza-se pela atividade de mineração praticada por mineiros: pequenos, médios ou grandes, legal ou ilegal, que utilizam procedimentos rudimentares para extrair minério de depósitos secundários ou primários. Essa atividade não emprega estudos de prospecção para localizar as jazidas, simplesmente baseiase no instinto do minerador (garimpeiro) para encontrar o minério (VEIGA et al., 2015). Em outras palavras, Prado Junior (1994), ao diferenciar a lavra mineradora industrial da artesanal praticada no século XVIII, descreve a lavra faisqueira como pequena exploração aurífera realizada por indivíduos isolados chamados de faiscadores os quais empregam instrumentos rudimentares. Os faiscadores não seguem regras, são nômades e geralmente migram de um lugar para outro para catar ouro. Era raro, mas podiam aglomerar-se em locais específicos por um pequeno tempo. Todavia, o trabalho diário do faiscador a procura de ouro era praticado de forma individual e isolado. Alguns faiscavam por conta própria, outros para os senhores dos escravos que determinavam um montante de ouro a ser entregue com uma certa frequência. Em outro tempo histórico, a mesma concepção teórica é vista nos escritos de Caheté, ao afirmar que o termo mineração artesanal (garimpagem) é caracterizada pelo trabalho individual ou por uma pequena equipe de garimpeiro que usando instrumentos de trabalhos rústicos, tais como bateia, picareta, pá, etc., com apoio ou não de maquinários que funcionam através de combustíveis fósseis. Estes extraem minérios confinados em depósitos existentes em terra firme ou nos cursos d'água (CAHETÉ, 1998).

No continente latino americano, os mineiros ou garimpeiros recebem diferentes denominações, que muitas vezes são derivadas de palavras regionais que em sua maioria apresentam significado pejorativo. É o caso do Brasil, cuja palavra "garimpeiro", foi incorporada a língua portuguesa no século XVIII em atribuição aos contrabandistas de diamantes que furtavam dos distritos onde a entrada de pessoas e o trabalho de mineração era ilegal (VEIGA et al., 2015). Porém, em 1970, o código de mineração brasileiro descaracterizou o sentido pejorativo desse termo, quando considerou garimpagem o trabalho individual de quem utiliza instrumento rudimentar ou máquinas simples e portáteis para extração de pedras preciosas, semipreciosas e minerais metálicos ou não metálicos, valiosos, confinados em depósitos de aluvião nos cursos d'águas ou nas margens, bem como nos depósitos primários situados no cume das chapadas e nas vertentes de morros. O ambiente de 
extração aurífera (primário ou secundário) genericamente recebe o nome de garimpo, enquanto o profissional que trabalha neste espaço é denominado garimpeiro (BERBERT, 2008).

Por outro lado, a "mineração industrial" caracteriza-se por utilizar como fonte energética predominante a energia elétrica para fazer movimentar um conjunto mais sofisticado de máquinas e ferramentas, operadas por uma equipe de profissionais especializados, muitas vezes organizados de forma hierarquizada por setores de produção com a finalidade de garantir uma maior capacidade de extração e produção mineral. Há um grupo de teóricos que caracterizam a atividade de mineração industrial como uma atividade essencialmente empresarial, pois necessita de uso intensivo de capital e inovação tecnológica, mas com baixa utilização de mão de obra. Desse modo, na mineração industrial podemos constatar que os poucos empregos fixos gerados na linha de produção normalmente exigi certa qualificação (CAHETÉ, 1998). Mas, por necessitar de certa infraestrutura mínima, essa atividade contribuí para um relativo crescimento econômico regional, através da geração de empregos indiretos, que em alguns casos permanecem mesmo depois de cessada a exploração mineral, peculiaridade esta não observada na mineração artesanal, basta lembrar Serra Pelada (PA) e a situação atual de desenvolvimento dos núcleos urbanos de Abunã (RO), Araras (RO), Periquitos (RO) e outros que praticamente desapareceram com a decadência da atividade de mineração aurífera do Rio Madeira.

Vários documentos oficiais (relatório de prospecção, portaria de autorização de lavra, decreto de criação de distrito aurífero, etc.) apontam que dentre todos os distritos auríferos que existiam na reserva garimpeira do Rio Madeira, os distritos de Abunã, Araras e Periquitos destacavam-se pela elevada concentração de ouro depositados nos aluviões, dos quais estimase que foram extraídos mais $30 \mathrm{t}$ de ouro. Caso todo este ouro fosse vendido ao valor $\mathrm{Cr} \$$ 39,00 (preço do grama do ouro comercializado em junho de $1989^{6}$ ), o grama do ouro, significaria um capital de Cz\$1.170.000.000. Deste montante, se algo entorno de 7 milhões de cruzados fosse repassado mensalmente na forma de royalties as comunidades situadas nas adjacências dos distritos auríferos, para serem aplicados em projetos de desenvolvimento sociais e econômicos, a realidade dos distritos de Arara, Abunã e da comunidade rural Periquitos seria bem diferente da atual. Um fato singular chama atenção, no que de respeita a

6 Histórico do preço do grama do ouro e da moeda nacional. Disponível em: http://www.ocaixa.com.br/bancodedados/ouro.htm Acesso em: 10 de fev.2016.

Fronteiras: Revista de História | Dourados, MS | v. 19 | n. 33 | p. 43 - 69 | Jan. / Jun. 2017 
estratégia do governo Federal diante dos achados auríferos, no trecho encachoeira do Rio Madeira, que ao invés de restringir a atividade de mineração aurifica artesanal (postura adotado na mineração estanífera) preferiu incentivar e ampliar a área geográfica de exploração de ouro no território rondoniense. Esta medida, em nenhum momento visava atender os anseios dos garimpeiros expropriados da área de lavra de cassiterita e ouro, mais sim evitar evasão de capital via exploração de recursos minerais pelas mineradoras transnacionais, uma vez que a maioria das concessões de exploração mineral no território brasileiro foram concedidas a empresas: estadunidenses, canadenses, japonesas e europeias (BECKER, 1991). Curiosamente, os mesmos estados nacionais, do qual o governo brasileiro tinha feito vultoso empréstimo no exterior.

Com base nos pressupostos apresentados anteriormente, pode-se inferir que a mineração artesanal é, por excelência, uma atividade que ocupa um grande quantitativo de trabalhadores autônomos, geralmente não especializados e tão poucos detentores de alguma patente tecnologia (inovação) relacionada a extração aurífera. Esse é o caso dos equipamentos utilizados nos garimpos do Rio Madeira, que são oriundos dos garimpos do Rio Tapajós. Esta característica é marcante em todo o ciclo de mineração aurífera (lavra manual, extração por balsas e dragas) ocorrido na reserva garimpeira do Rio Madeira.

\section{Evolução dos métodos de produção empregados na exploração aurífera e a migração de garimpeiros para o território rondoniense}

Na segunda metade do século XX, precisamente em 1978, durante a segunda corrida aurífera ocorrida na Amazônia, iniciou-se de forma incipiente a garimpagem de ouro no noroeste rondoniense, nas proximidades da localidade onde Luis de Alincourt registrou a presença de fagulhas de ouro no princípio do século XIX. A notícia da existência de ouro nos aluviões do Alto Rio Madeira espalhou-se para outras áreas de mineração, instaladas na periferia da Amazônia Legal e Internacional. Informação que originou novamente uma expressiva migração externa (Guiana, Cuba, Colômbia, Bolívia etc.) e, sobretudo, interna (inter e intra-regional) de garimpeiros em direção ao então Território Federal de Rondônia.

No fim da década de 1970 havia na região do Alto Rio Madeira um contingente populacional superior a 8.000 garimpeiros em várias frentes de garimpagem de "lavra manual” (primeiro método de inovação), especialmente nas imediações das localidades de Abunã (RO), antiga Mutum-paraná (RO) (inundada com a construção da Usina Hidroelétrica 
de Jirau) e Jaci-paraná (RO). Sobre o processo de migração de garimpeiros, o IBGE (1975) informa que:

[...] Apesar da perda de importância relativa do efetivo rural, no conjunto do Território, quando analisado por distritos verifica-se que Rondônia é, ainda, uma região essencialmente rural. No distrito de Jaciparaná verificou-se uma retomada do crescimento rural, pois no período 1950/1960, o distrito de Jaciparaná foi uma área de expulsão da população do campo $(-21,10 \%)$ e, na segunda década, tornou-se foco de atração, tendo apresentado crescimento relativo de $32,33 \%$, com uma amplitude de $53,43 \%$. Neste localizam-se as áreas de extração de cassiterita e ouro que, na última década, começou a ser explorada em maior escala [...] (IBGE 1975, p. 21).

Nessas localidades, mais tarde o Departamento Nacional de Pesquisa Mineral (DNPM) liberou oficialmente a exploração mineral artesanal (ouro), através das portarias $\mathrm{n}^{\circ}$ 1345/79 e 1034/80, após prospecções demonstrarem abundantes depósitos secundários de ouro nas adjacências das comunidades de Periquitos e Abunã (DNPM, 1979; DNPM, 1980). A partir dessa área ocorreu uma rápida e contínua proliferação de setores de garimpagem, inclusive, em áreas não liberadas oficialmente, estendendo-se da cachoeira do Paredão (192 km de Porto Velho) ao vilarejo de São Carlos do Rio Madeira (Figura 1) (LINHARES, et al., 2009; CPRM, 1999).

Todavia, são poucos os habitantes que migraram ou nasceram no período da segunda grande corrida de exploração aurífera ocorrida no território rondoniense e, em outras partes da Amazônia Legal, que têm conhecimento do real significado que envolveu a criação das reservas garimpeiras do Rio Madeira (Rondônia), entre outras, instituídas durante o governo do general João Batista de Oliveira Figueiredo nos estados de Mato Grosso, Pará e Roraima.

A homologação destas áreas de mineração não visava atender uma política de desenvolvimento regional, tão pouco, prover assistência de qualquer tipo aos garimpeiros que migraram para trabalhar nestes confins da Amazônia. Na realidade, essas homologações foram promovidas pelo governo brasileiro a fim de aumentar as reservas monetárias do Banco Central Brasileiro (BCB) na tentativa de tirar o País da crise econômica da década de 1980. Crise que foi associada ao aumento do preço do barril de petróleo pela Organização dos Países Exportadores de Petróleo (OPEP) que resolveu reajustar os preços do petróleo com intuito de recuperar os lucros perdidos que vinham ocorrendo desde os anos de 1950. 
Figura 1: Localização das antigas frentes de garimpeiras do rio Madeira - RO.

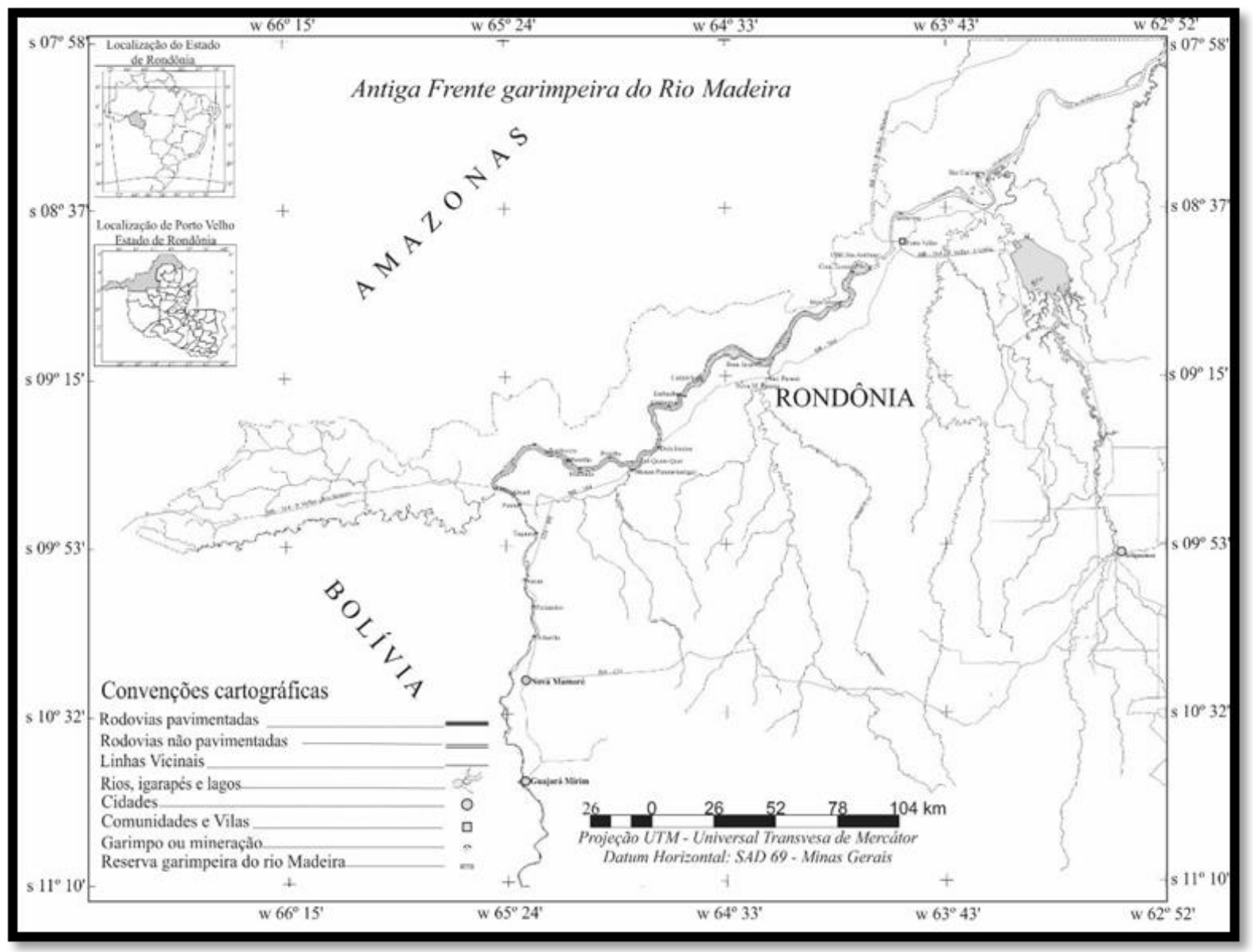

Fonte: Mapa da reserva garimpeira do rio Madeira do DNPM (1983) e IBGE (1981)․

De fato, a crise econômica que causou profunda recessão na economia brasileira foi ocasionada pelo endividamento do governo brasileiro no exterior, pela política de desvalorização do salário mínimo e principalmente, pela concentração de renda (ricos cada vez mais ricos e pobre tornando-se miseráveis). O governo ditatorial mantendo-se inflexível na sua política econômica interna, baseada no arrocho salarial e má distribuição de renda, para enfrentar a crise econômica preferiu tomar novos empréstimos no exterior, apostando no crescimento das exportações em que os lucros, boa parte transformados em impostos, dariam condições de pagar a dívida externa e ainda sobraria alguns trocados na poupança do BCB. Porém, isso não aconteceu. Na verdade, a crise aprofundou-se até os anos de 1990. É nesse

\footnotetext{
${ }^{7}$ As informações temáticas referentes, a rede de drenagem, sistema rodovia e localização das áreas urbanas, vilas e comunidades foram obtidas do banco de dados digital de carta topográfica folha Porto Velho - 1:100000. Do Ministério do Exército / Diretoria de Serviço Geográfico. Brasília: DSG/IBGE, 1982.
}

Fronteiras: Revista de História | Dourados, MS | v. 19| n. 33 | p. 43 - 69 | Jan. / Jun. 2017 
contexto que entram em cena os milhares de garimpeiros que, ao migrarem para a Amazônia propiciaram uma produção aurífera recorde no ano de 1983 no garimpo de Serra Pelada e na reserva garimpeira do Rio Madeira. Nesta última frente de garimpagem a produção oficial registrada atingiu $3.454 \mathrm{Kg}$ de ouro, mas os órgãos oficiais estimam que a produção possa ter superado os $8.000 \mathrm{~kg} / \mathrm{Au}$, somada a produção clandestina. Episódio que vai se repetir quatro anos mais tarde (1987), quando a produção de ouro nos garimpos rondoniense supera o dobro da produção anterior, chegando a triplicar no início dos anos de 1990 (PINTO, 1993; ADAMY, 1991).

Os comerciantes da antiga sociedade portovelhense vivenciaram esse momento inusitado da economia rondoniense, propiciada pela mineração aurífera artesanal, pois, enquanto os grandes centros comerciais do sudeste reclamavam sobre os efeitos da crise econômica que assolava o país, o garimpeiro bamburrava (sucesso financeiro) nas várias frentes de extração de ouro na reserva garimpeira do Rio Madeira, aqueciam o mercado varejista nas cidades de Porto Velho, Guajará Mirim e, através de filiais instaladas nas corrutelas (cidadelas improvisados), situadas nas adjacências dos garimpos. Neste espaço e tempo, curiosamente a moeda corrente, nas transações econômicas locais eram aferidas em gramas de ouro. Será que algum comerciante ou garimpeiro rondoniense participou da conferência de Bretton Woods de 1944, quando uma onça de ouro passou a valer US\$ 35 ? (SIMON, 2011). Era comum na compra de qualquer produto e/ou serviços, principalmente aqueles oferecidos nas casas populares de entretenimento, o pagamento em dinheiro (Cruzeiro) ou em ouro.

Todavia, comerciantes e garimpeiros não sabiam que uma parte significativa do ouro que circulava no comércio local, não levava mais do que três ou quatro dias, entre o processo de extração e comercialização para chegar ao sul do País. Transferência de riqueza que era realizada através dos estabelecimentos comerciais (privados e estatais) especializados, instalados próximos das reservas garimpeiras, com a finalidade de capitar a maior quantidade possível de ouro. Foi dessa forma que o governo brasileiro capitalizou-se e conseguir saldar uma parte considerável dos juros da dívida externa do Brasil, além de reduzir a recessão econômica (PINTO, 1993).

A estratégia do governo militar de institucionalizar as áreas de mineração artesanal amazônica deu tão certo que com a finalidade de aumentar ainda mais a capitalização de recursos, o Ministério de Mina e Energia (MME) na época criou o "Programa Nacional de 
Ação Integrada para o Ouro" e a "Política Nacional de Ouro". Estas medidas transformaram a reserva garimpeira do Alto Rio Madeira em uma área de atração populacional, porém, os objetivos dos programas não foram alcançados.

Com a esperança de enriquecimento rápido, diariamente desembarcavam no terminal rodoviário de Porto Velho-RO centenas de garimpeiros, que posteriormente aglomeravam-se nos pequenos núcleos urbanos (Abunã, Jaci-paraná etc.) situados às margens da rodovia BR 364, no trecho que interliga Porto Velho-RO ao distrito de Abunã-RO. Esses por motivo da ascensão da mineração aurífera artesanal experimentaram um relativo progresso econômico, apesar da produção de ouro ainda ser muito limitada, não ultrapassando em 19791.700 Kg. A baixa produção, era um fenômeno característico nos garimpos de ouro existentes na Amazônia, pois usavam métodos (inovação) de exploração rudimentar, semelhante àqueles observados na primeira corrida do ouro acontecida no século XVIII (BASCOPÉ, 1991).

No princípio dos anos oitenta um novo método (segundo método ou inovação) de extração mineral foi introduzido, o qual provocou uma mudança expressiva na produção aurífera e na migração de garimpeiros para o Alto Rio Madeira. Nesse período, são introduzidas as primeiras balsas garimpeiras, uma espécie de embarcação rústica composta por dois botes de madeira, com cerca de 6 a 7 metros de comprimento, unidos por pranchas de madeira, onde são instalados motores estacionários (10 HP a 32 HP) acionados a gasolina ou diesel. A esses são acopladas bombas de sucção que passaram a extrair dos depósitos sedimentares de aluvião, no leito rio Madeira, uma mistura de material detrítico composto por água, cascalho, sedimento e fragmentos finíssimos de ouro. O processo de garimpagem era desenvolvido durante uma longa jornada de trabalho, onde cada garimpeiro mergulhava por aproximadamente cinco horas. As equipes eram formadas por um mergulhador, um operador de máquina responsável pela comunicação e o fornecimento de ar ao mergulhador que estava mandando matéria do fundo do rio para a superfície e um terceiro responsável pela remoção do rejeito acumulado nas peneiras metálicas da caixa concentradora, popularmente denominada pelos garimpeiros de "cobra fumando". Após 10 a 15 horas de trabalho árduo, finalmente ocorria a despescagem e a apuração da produção do ouro, cujo montante extraído era dividido na proporção de $50 \%$ a $60 \%$ entre o proprietário da balsa e maquinário e os outros $50 \%$ a $40 \%$ entre os garimpeiros (BASTOS, 1988).

Em 1985, a garimpagem de ouro no leito do Rio Madeira com uso de balsa (Figura 2) atingiu seu auge, quando a produção ultrapassou os $3.500 \mathrm{Kg}$ ouro/ano. Na ocasião estimava- 
Exploração aurífera artesanal e a migração de garimpeiros para o território rondoniense - Joiada Moreira da Silva Linhares; Wanderley Bastos Rodrigues; José Manoel Carvalho Marta

se que estavam em operação mais de 800 balsas, sendo que os principais setores de garimpagem situavam-se nas comunidades de Morrinhos (100 balsas) e nos garimpos do Tamborete (180 balsas), Ilha do Machado (30 balsas), Ribeirão (200) e outros. Nesse novo cenário, estavam envolvidos diretamente na extração de ouro, mais de 10.250 trabalhadores. E indiretamente mais de 7.500 pessoas, empregadas em diversas atividades informais dando suporte em terra firme às equipes de garimpagem que estavam trabalhando embarcados nas balsas ambiente fluvial (ADAMY, 1983).

Figura 2: (A) balsa garimpeira em operação na frente de garimpagem do rio Madeira - RO, (B) Garimpeiro mergulhador do garimpo de Morrinhos - rio do Madeira - RO

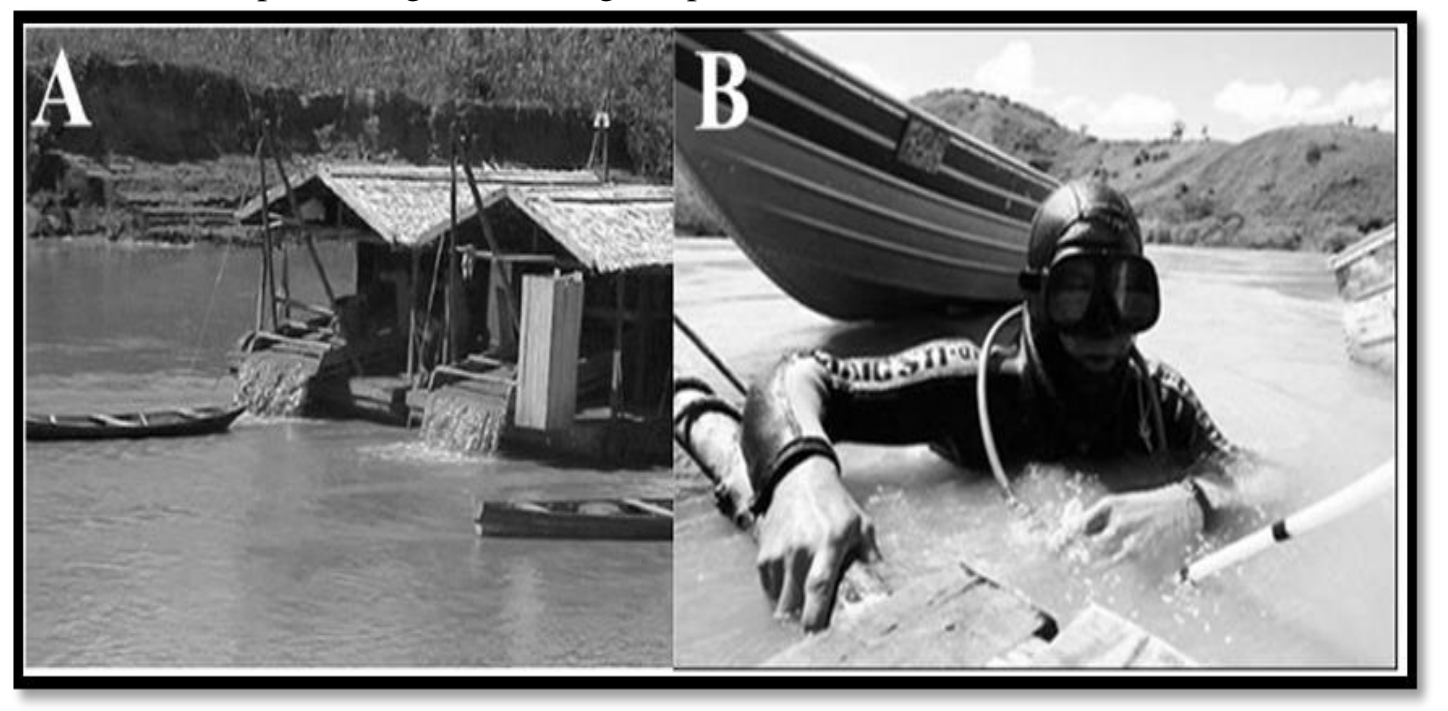

Fonte: (a) Laboratório de Biogeoquímica Ambiental (BASTOS, 2004). (b) ilustração publicada no site de notícia gentedeopinião ${ }^{8}$.

No mesmo período em que foram introduzidas as primeiras balsas, o Departamento Nacional de Pesquisas Minerais (DNPM) autorizou, em caráter experimental, a utilização de dragas na extração de ouro nos garimpos de Rondônia. Entretanto somente após 1986, essas (terceiro método ou inovação) passaram a ser largamente empregadas na mineração aurífera no Rio Madeira (BASTOS, 1988).

A draga possui uma estrutura mecânica mais elaborada que as balsas, pois são constituídas por dois tubos metálicos com cerca de catorze metros de comprimento, unidos por vigas de ferro ou pranchões de madeira, sobre os quais são montadas bombas de sucção acionadas por motores automotivos, geralmente Mercedes Benz a diesel de 500 HP. Estas,

8 Ilustração compilada da matéria intitulada - Organização do garimpo uma utopia. Disponível em: http://.www.gentedeopinião.com.br. Acesso em: 20 dez. 2014. 
conforme a capacidade operacional possuíam três versões: i) draga "queixo duro", pioneira nos garimpos rondoniense, recebia este nome devido a tubulação de sucção possibilitar pouquíssima mobilidade vertical em relação à lâmina d' água; ii) "draga de lança", diferenciava-se da primeira devido à maior movimentação da estrutura de dragagem, tendo tubos mais amplos; e iii) “draga escariantes” recebe esta denominação por possuir uma broca (denominado de abacaxi na linguagem dos garimpeiros) escarificadora na extremidade da lança, usada na desagregação de sedimentos mais coesos (mocororó), ampliando a capacidade de exploração mineral (ADAMY, 1991; ADAMY, 1981).

Apesar da draga garimpeira necessitar de investimento de capital inicial mais elevado que a balsa, o seu custo com manutenção era menor, e a equipe era mais reduzida, pois era desnecessário os mergulhadores no processo de extração de cascalhos mineralizados. Além disso, tinha capacidade de lavrar um volume maior de material, logo extrair maior quantidade de ouro que em outros ciclos de exploração aurífera.

Assim, entre 1987 e 1992, a mineração aurífera no Alto Rio Madeira atingiu seu apogeu (pico de maior prosperidade), tornou-se mais especializada, com uma relativa mecanização através das dragas garimpeiras que passaram a ser o principal meio de extração de ouro no garimpo do rio Madeira. Segundo levantamento realizado pela Federação das Indústrias e Comércio de Rondônia (FIERO, 2003), estima-se que neste período havia mais de 600 dragas (Figura 3) envolvidas na exploração de ouro, o que propiciaram um aumento rítmico na produção e na migração de garimpeiros superior aos registrados nos ciclos de lavra manual e extração por meio de balsas garimpeiras. 
Figura 3: (A) Dragas em operação nas proximidades do distrito de São Carlos - RO. (B) Dragas sendo rebocadas na área da reserva garimpeira do rio Madeira - RO

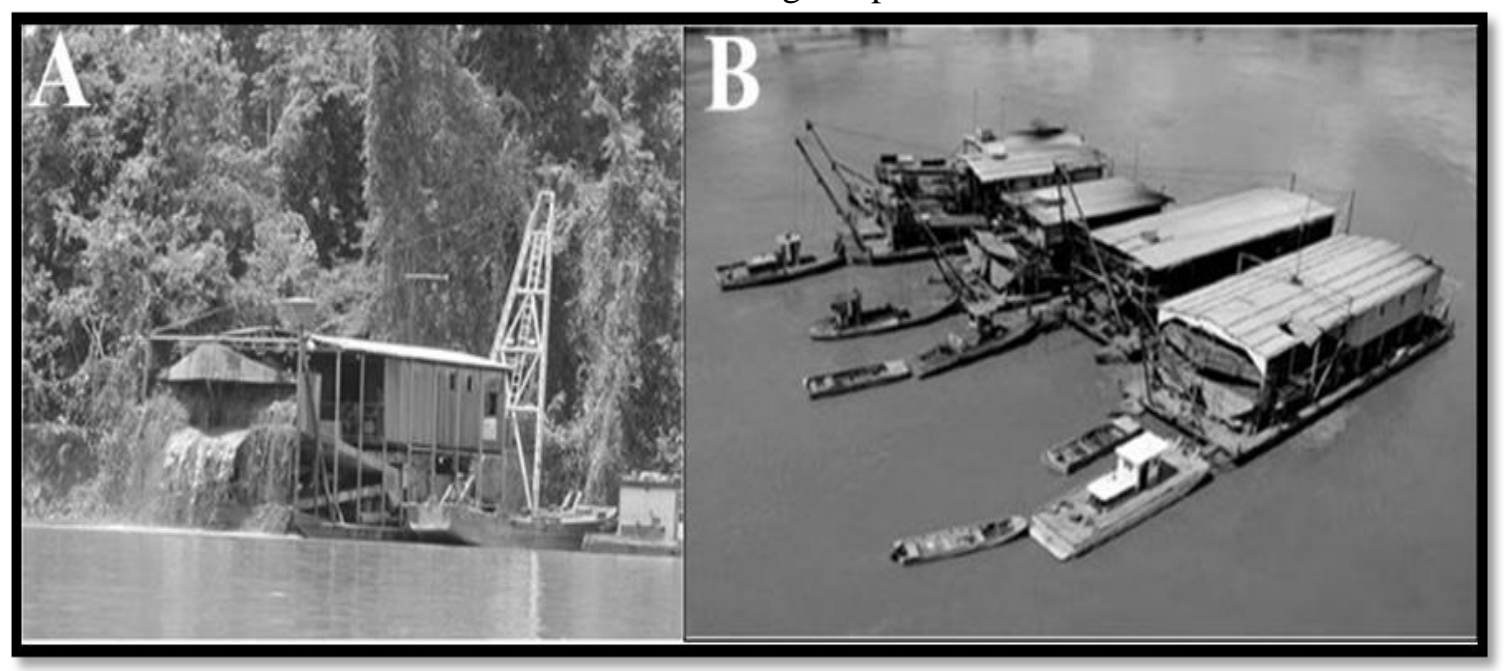

Fonte:(A) Laboratório de Biogeoquímica Ambiental (B) Foto de Pedro Martinelli.

Até hoje não se sabe o volume exato de ouro extraído nos garimpos do Rio Madeira e muito menos o quantitativo de mercúrio usado e despejado na calha do rio e na atmosfera. Calcula-se que até meados da década de 1990 havia uma produção superior a 5t ano, após este período houve um forte declínio (depressão) da produção aurífera em Rondônia (BASTOS, 2004).

Sem dúvida, a mineração artesanal desenvolvida no rio Madeira é marcada pela evolução de métodos de exploração aurífera da atividade de garimpagem. Esta proporcionou ao longo de mais duas décadas (1978 a 1999) momentos de elevada produção de ouro e, euforia de bem-estar econômico da população residente nas adjacências da frente de garimpeira do Rio Madeira. A inserção de balsas garimpeiras significou a superação de obstáculos naturais da relação homem/natureza pela busca desenfreada por riqueza (MARTHIS, 1995). Com este propósito, centenas de garimpeiros, oriundos de outras regiões do país, fizeram fortunas nos garimpos rondonienses, como se diz na linguagem usual do garimpo voltaram a seus estados de origem "bamburrados". Outros não tiveram a mesma sorte e perderam suas vidas trabalhando na esperança de ficarem ricos de uma hora para outra. Esses e muitos outros trabalhadores autônomos fazem parte do triste legado deixado pela mineração aurífera ocorrida no território rondoniense.

${ }^{9}$ (a) Imagem produzida pela doutoranda Marilia Mussy, durante o trabalho de campo realizado em setembro de 2013. (b) Ilustração retirada da matéria - Amazônia perde mais de 2 bi em ouro roubado de áreas das cooperativas. Disponível em: http://www.newsrondonia.com.br/noticias/amazonia. Acesso em: 14 jan. 2014.

Fronteiras: Revista de História | Dourados, MS |v. 19 |n. 33 |p. 43 - 69 | Jan. / Jun. 2017 
Por outro lado, há quem possa pensar que a versão mais moderna de draga, denominada de escariante, ainda em pleno funcionamento em vários pontos de garimpagem no rio Madeira, seja símbolo de desenvolvimento tecnológico no processo de extração aurífera. No entanto, seus equipamentos de operação mecanizada servem apenas para dragagem de um grande volume de sedimentos, associados ao minério aurífero do fundo do leito do rio, à caixa concentradora. Assim, o tratamento e o beneficiamento final para obtenção de ouro até hoje continua sendo realizado de modo tão atrasado quanto aqueles empregados na mineração brasileira do século XVII e início do século XVIII. Essas semelhanças não param por aí, pois o que difere a técnica de recuperação do ouro empregado pelos faiscadores no período colonial da técnica praticada pelos mineradores artesanais do Rio Madeira (Rondônia), em plena era técnica-tecnológica informacional capitalista, é a substituição de peles de animais por carpetes de algodão ou poliéster, usados no revestimento do fundo da caixa concentradora a fim de reter maior quantidade de minério. Porém, esses artefatos não contribuem para reduzir a perda de ouro, que é em torno de 40\%, o que nos leva a refletir que o declínio acentuado (recessão) da mineração artesanal na reserva garimpeira do Rio Madeira, ocorrido em meados da década de 1990, não foi simplesmente motivada pelo esgotamento dos depósitos mineralizados auríferos, mas devido à ausência de tecnologia eficiente na recuperação do minério (ADAMY, 1991; SANTOS, 2002). O mecanismo de perda pode ser confirmado na citação que se segue:

[...] se perde ouro na retirada do material do solo e no seu tratamento, e essa perda vai para os rejeitos que, em geral, se espalham para áreas dispersas de difícil recuperação futura por qualquer empresa de mineração. O que se disse aqui para o ouro é verdadeiro, em parte, também para cassiterita e outros minérios.

Enfim, a ganância de produzir riqueza rápida, principalmente em áreas excepcionalmente ricas, nestes últimos 12 anos, inibiu a evolução de processos tecnológicos de recuperação dos metais, causando grandes prejuízos ao país [...] (BERBERT; ARAÚJO NETO, 2008, p. 236).

Os indicadores de produção e comercialização de ouro denotam que a garimpagem na bacia do Rio Madeira entrou em uma fase de resseção. Porém, não é a primeira vez que a atividade de mineração artesanal rondoniense passa por uma crise desse porte. Cabe lembrar que em 1986 a produção aurífera nos garimpos de Rondônia caiu acentuadamente, não ultrapassando os $500 \mathrm{Kg}$ de ouro. Naquele período, a imprensa local noticiava um possível esgotamento das jazidas secundárias e o fim da garimpagem no Rio Madeira. Após este episódio, a atividade de mineração aurífera artesanal do Rio Madeira atingiu uma 
produtividade histórica, superior a $9.610 \mathrm{Kg}$ de ouro/ano. Por isso, é muito cedo para falar de esgotamento total das jazidas de ouro na bacia do Rio Madeira, uma vez que há espalhado por todo o território rondoniense vários depósitos primários e secundários de ouro a serem explorados (Figura 4).

Figura 4: Principais depósitos, ocorrências e indícios de ouro no território rondoniense

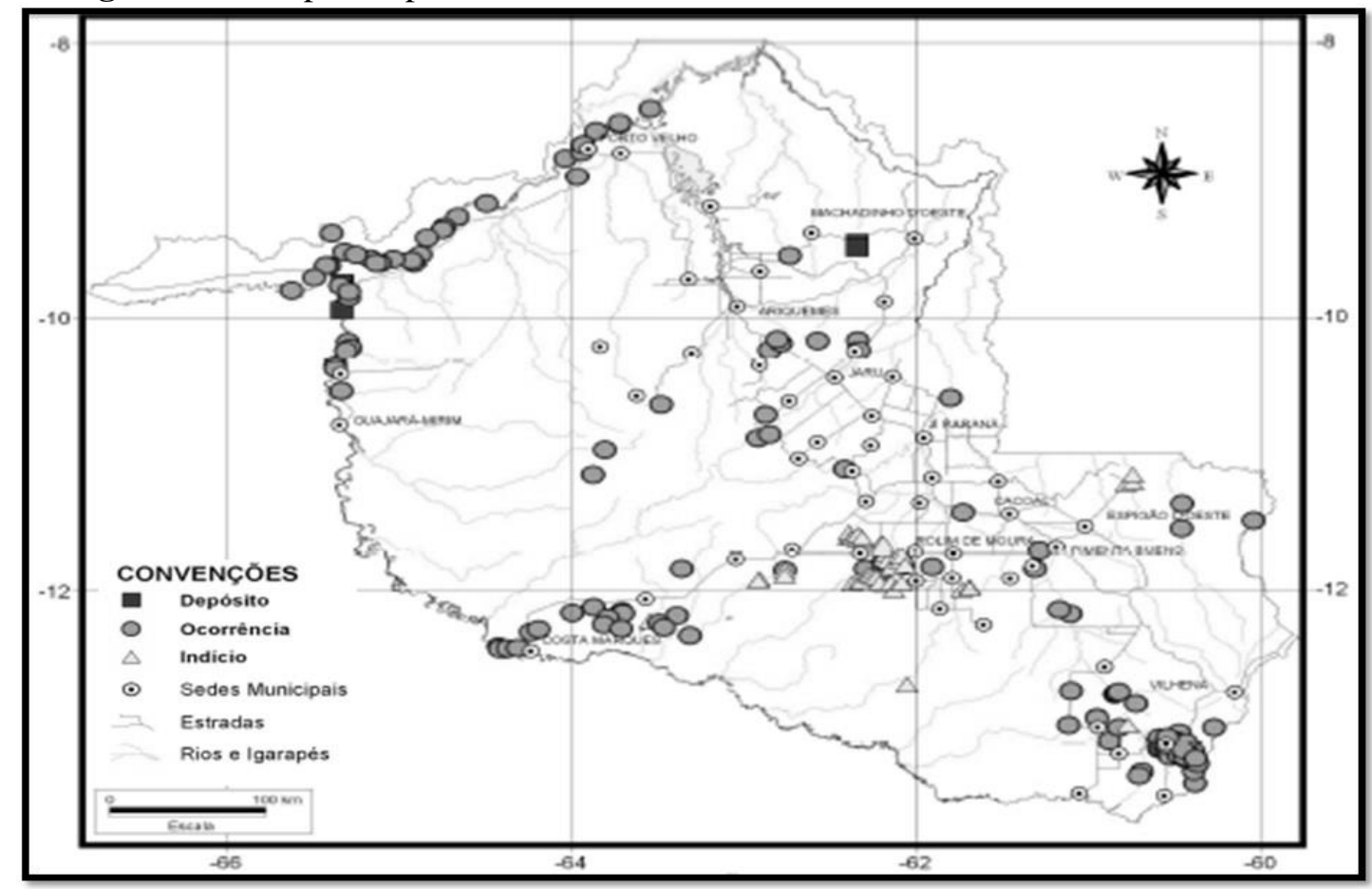

Fonte: Quadros (2007).

\section{Considerações Finais}

Ao longo da história de exploração mineral ocorrida na Amazônia, talvez a bacia do Rio Madeira (Rondônia) seja a única das grandes sub-regiões hidrográficas brasileiras aonde ocorreu cinco ciclos econômico de exploração aurífera artesanal. O primeiro (ciclo de ondas longas), entre 1721 e 1765, relaciona-se à descoberta das jazidas de ouro (matéria prima de alto valor econômico) cuiabanas e guaporeanas. Estas originaram a migração (externa e interna) de garimpeiros para o vale do Rio Guaporé, o surgimento da capitania de Vila Bela da Santíssima Trindade entre outros povoadas na região de fronteira Brasil-Bolívia. O segundo (ciclo de ondas médias), entre 1952 e 1970, refere-se a descoberta de uma nova fonte de matéria prima, a cassiterita. A extração deste minério atraiu milhares de garimpeiros com e 
sem experiência para o Território Federal de Rondônia. O terceiro, o quarto e o quinto são ciclo econômicos oriundos da introdução de métodos de extração de ouro. Entre 1978 e 1981, as migrações de garimpeiros ocorreram devido à descoberta de jazidas auríferas secundárias, que começaram a ser exploradas através da lavra manual. De 1981 a 1985, a extração de ouro na reserva garimpeira do Alto Rio Madeira passou a ser feita através de balsas garimpeiras. Essa inovação significou o início da divisão social do trabalho extrativista mineral nos garimpos de Rondônia. Fato que atraiu um contingente populacional numeroso de garimpeiros para trabalhar embarcado e em terra firme. Entre 1986 e 1992, foram introduzidas as dragas garimpeiras. Método de extração que excluiu a figura do garimpeiro mergulhador, porém propiciou o aumento expressivo da produção e, ao mesmo tempo, da migração de garimpeiros especializados em operação e manutenção de motores estacionários.

O maquinário empregado em trinta anos de exploração mineral nos garimpos rondonienses, não é reflexo do desenvolvimento de uma base tecnológica local, uma vez, que os garimpeiros capitalizados ou proprietários dos meios de produção montavam as dragas garimpeiras a partir da aquisição de equipamentos trazidos para o noroeste rondoniense na forma de pacote tecnológico pronto e acabado. Geralmente produzidos por outras sociedades externas ao espaço Amazônico. Além disso, não há nos relatórios da Federação de Indústria e Comércio de Rondônia (FIERO) informação referente à instalação em Rondônia de montadoras multinacionais de motos estacionais, automotivos e náuticos, com a finalidade de atender a demanda da mineração aurífera regional. Portanto, os equipamentos oriundos de outras regiões, que foram incorporados no processo produtivo de extrativismo mineral, a exemplos das balsas e posterior das dragas garimpeiras, inviabilizaram a difusão de algumas tecnologias para outras atividades, quando a mineração aurífera artesanal rondoniense entrou na fase de resseção.

Apesar disso, de certo modo, o ouro produzido pelos garimpeiros ou faiscadores no território rondoniense, contribuiu para o desenvolvimento econômica europeu e brasileiro, pois no período colonial, das minas mato-grossenses do vale do Guaporé, os portugueses levaram à Europa o ouro brasileiro, naquele continente ele era negociado com os ingleses na compra de produtos manufaturados. Mercado que acelerou o desenvolvimento industrial Inglês. Das reservas garimpeiras como Serra Pelada, Rio Madeira entre outras, o ouro produzido e comercializado nos garimpos da Amazônia, ajudou o governo brasileiro a 
acumular capital suficiente para saldar uma parte da dívida externa do país junto aos bancos internacionais, europeus e estadunidenses.

Ao povo amazônico (boliviano e brasileiro) das diversas frentes de garimpagem, restou um modesto desenvolvimento regional, inúmeros problemas socioambientais e a incerteza sobre a salubridade do ambiental habitado principalmente pelas comunidades ribeirinhas, quanto aos níveis de mercúrio no ecossistema aquático do Rio Madeira, Rondônia.

\section{Referências}

ADAMY, Amílcar. Projeto Estudo de garimpos brasileiros: reserva garimpeira do rio Madeira. (Relatório técnico anual, v. 01) Porto Velho: CPRM, 1981.

ADAMY, Amílcar; PEREIRA, Luiz. Antônio Costa. Garimpos de ouro no rio Madeira Rondônia. (Relatório técnico, v. 01). Brasília: DNPM, 1983.

ADAMY, Amílcar; PERREIRA, Luiz Antônio Costa. Projeto ouro gemas - Rondônia. Porto Velho: CPRM. 1991.

ALINCOURT, D'Luis. Memória sobre a viagem do porto de Santos à Cidade de Cuiabá / Luís D' Alincourt. Brasília: Senado Federal, 2006. Disponível em: <http://www.senado.gov.br/web/conselho/conselho.htm>. Acesso em: 20 set. 2015.

AMARAL, Antônio Rodrigues do; LIMA Filho, Clóvis. Ártico. Curso de mineralogia. Disponível em: <http://www.dnpm-pe.gov.br>. Acesso em: 14 jan. 2016.

BASCOPÉ, Gaston Pereira; D’Alvear, Roberto Lobo. Garimpos do médio rio Madeira Rondônia. (Relatório técnico, v. 1). Rio de Janeiro: CPRM, 1981.

BASTOS, José Belfort dos Santos. Depósito de ouro do rio Madeira - Rondônia. In: SCHOBBENHAUS, Carlos; COELHO, Carlos Eduardo Silva. (Coordenação geral) Principais depósitos minerais do Brasil. Brasília: DNPM/CVRD. 1988. p. 576-580.

BASTOS, Wanderley Rodrigues e LACERDA, Luiz Drude. Contaminação por mercúrio na Bacia do Rio Madeira: uma breve revisão. Revista Geochimica Brasiliensis, n.18, p. 99 - 114, 2004.

BASTOS, Wanderley Rodrigues. Ocorrência ambiental do mercúrio e sua presença em populações ribeirinhas do baixo rio Madeira-Amazônia. 2004. 113 f. Tese (Doutorado em Ciências) - Universidade Federal do Rio de Janeiro. Rio de Janeiro, 2004.

BECKER, Bertha Kassilda. Amazônia. 2 ed. São Paulo: ática, 1991 
BERBERT, Carlos Oiti; NETO, Araújo Homero. O problema dos garimpos na Amazônia. In: PAVAN, Crodowaldo. Uma estratégia latino-americana para a Amazônia. São Paulo: UNESP, v. 2, p. 227-240, 2008.

CAHETÉ, Frederico. Extração do ouro na Amazônia e suas implicações para o meio ambiente. Novos Cadernos NAEA. Belém, v. 1, n. 2, 1998. Disponível em: <http://www.periodicos.ufpa.br/index.php/ncn/article/view/14/13>. Acesso em: 18 dez. 2015.

CANOVA, Loiva. Antônio Rolim de Moura e as representações da paisagem no interior da Colônia Portuguesa na América (1751-1764). 2011. 319 f. Tese (Doutorado em História) Universidade Federal do Paraná. Curitiba, 2011.

CARDOSO, Ciro Flamarion e VAINFAS, Ronaldo. História e análise de texto. In: CARDOSO, Ciro Flamarion e VAINFAS, Ronaldo (Orgs). Domínios da História. Ensaios de teoria e Metodologia. 5 ed. Rio de Janeiro: Campus, 1997. cap. 17. p. 536-567.

Companhia de Pesquisa de Recursos Minerais - CPRM. Geologia e Recursos Minerais do Estado de Rondônia: texto e mapa geológico do Estado de Rondônia. Brasília: CPRM 1999.

DAMIANI, Amélia Luisa. População e geografia. 9. ed. São Paulo: Contexto, 2009.

Departamento Nacional de Produção Mineral - DNPM, Portaria $\mathrm{n}^{\circ}$ 1034, de 31 de julho de 1980, Brasília: 1980. Disponível em: 〈http://www.dnpm.gov.br〉. Acesso em: 1 out. 2015.

Departamento Nacional de Produção Mineral - DNPM, Portaria $\mathrm{n}^{\circ} 1345$, de 10 de julho de 1979, Brasília: 1979.Disponível em: 〈http://www.dnpm.gov.br>. Acessado em: 01 out. 2015.

DNPM - Departamento Nacional do Produção Mineral. Garimpos de Brasil. Brasília: DNPM, 1983.

FARIAS JUNIOR, Emmanuel de Almeida. Negros do Guaporé. O sistema escravista e as territorialidades específicas. Revista do Centro de Estudos Rurais. Campinas, v. 5, n. 2, p.85$116,2011$.

FERREIRA, Manoel Rodrigues Nas Selvas Amazônicas. São Paulo: Biblos editora, 1961.

FERREIRA, Maria Madalena. Do reco ao melechete. Uma leitura geográfica do garimpo do Bom Futuro - Extração de cassiterita, Ariquemes. Rondônia, Dissertação (Mestrado em Geociências) Universidade de São Paulo. São Paulo, 1996.

FIERO - Federação das Industriais de Rondônia. Perfil Socioeconômica Industrial de Rondônia. Porto Velho: SEBRAE/FIERO, 2003.

Instituto Brasileiro de Geografia e Estatística - IBGE. Atlas de Rondônia. Rondônia: IBGE, 1975.

LINHARES, Deborah Pereira; SILVA, Joiada Moreira da; LIMA, Tatiane Rodrigues. GOMES, João Paulo; RONALDO, Almeida; WANDERLEY, Rodrigues Bastos. Mercúrio 
em diferentes tipos de solos marginais no baixo rio Madeira - Amazônia Ocidental. Geochimica Brasiliensis. Recife, v. 23, n. 1, p. 117-130, 2009.

MARTHIS, Armin. Garimpagem de ouro na Amazônia. Papers do NAEA, Belém, n. 37, abril p. 1-13, 1995.

MARTINS, Dora; VANALLI, Sônia. Migrantes. 3. ed. São Paulo: Contexto, 1997.

PERDIGÃO, Francinete e BASSEGIO, Luiz. Migrantes Amazônicos. São Paulo: Loyola, 1992.

PINTO, José. Garimpagem: contribuição ao desbravamento e à ocupação da Amazônia. In: MATHIS Armin \& REHAAG Regine. (Org.). Consequências da garimpagem no âmbito social e ambiental da Amazônia. Pará: Graficentro, 1993, p. 27-35.

PORTO, Cláudio Gerhein; PALERMO, Nely; PIRES, Fernando Roberto Mendes. Panorama da exploração e produção do ouro no Brasil. In: TRINDADE, Barros. Emery; BARBOSAFILHO. Olavo. Extração de ouro: princípios, tecnologia e meio ambiente. Rio de Janeiro: CETEM/ MCT. Disponível em: <http://www.cetem.gov.br/publicacao/...ouro/capitulo_01.pdf>. Acesso em 26/01/2016.

PRADO JUNIOR, Caio. A mineração e a ocupação do Centro-Sul. In: História econômica do Brasil. São Paulo: 42 ed. Brasiliense, 1994.

QUADROS, Marcos Luiz.do Espírito Santos. RIZZOTTO, Gilmar. José. Geologia e recursos minerais do estado de Rondônia. Porto Velho-RO: CPRM, 2007. 1 CD-ROM.

QUEIROZ, Paulo Roberto Cimó. Uma esquina nos confins do Brasil: o Sul do Mato Grosso colonial e suas vias de comunicação (projetos e realidades). Revista Fronteiras. Dourados, v. 11, n. 19, p. 197-227, jan. / jun. 2009.

RAMOS, Carlos Romano. Estanho na Amazônia: o apogeu e acaso da produção. Novo caderno do NAEA. Belém, v. 6, n. 2, p. 39-60, dez. 2003.

RUSSELL-WOOD, Anthony. John. R. O Brasil colonial: o ciclo do ouro, c. 1690-1750. In: BETHEL, Leslie (Org.). América Latina colonial. São Paulo: Edusp/FUNAG, 1999, p. 471 525.

SANTOS, Breno Augusto dos. Recursos minerais da Amazônia. Estudos Avançados. São Paulo, v.16, n. 45, p. 123-152, 2002.

SCHUMPETER, Joseph Alois. Teoria do desenvolvimento econômico. São Paulo: Nova Cultural, 1997.

SILVA Arnaldo, Garimpo do Arara / RO depois do eldorado. Dissertação (Mestrado em Geociências) - Universidade Estadual Paulista. Rio Claro, 2002. 
SIMON, Silvana. De Bretton Woods ao Plano Marshall: a política externa norte-americana em relação à Europa (1944-1952). Revista Unicuritiba. Curitiba, v.2, n. 14, p. 24 - 47, 2011.

TEIXEIRA, L. S. Dinâmica territorial do Iata. Revista Geographia Oportuno Tempore, v. 1, n. 2, p. 52-64, 2014.

TEIXEIRA, Marco Antônio Domingues; FONSECA, Dante Ribeiro. História regional Rondônia. Porto Velho: AGB, 1998.

VEIGA Marcello M; HINTON Jennifer J. Abandoned Artisanal Gold Mines in the Brazilian Amazon: A Legacy of Mercury Pollution. Natural Resources Forum, v. 26, p.13 - 24, 2002.

VEIGA, Marcello Moriz da; SILVA, Rogério Alberto B. HINTON, Jennifer J. O garimpo de ouro na Amazônia: aspectos tecnológicos, ambientais e sociais. CETEM. Disponível em: $<$ http://www.cetem.gov.br/publicacao/extracao_de_ouro/capitulo_11.pdf $>$. Acesso em: 14 jan. 2015. 